\title{
Synthesis and research of polyfunctional silylureas used in electric deposition of tin-indium alloy
}

\author{
K.Yu. Ivanova * (1), M.V. Kuzmin (D), L.G. Rogozhina (D), A.O. Patianova (D), \\ V.L. Semenov (1), R.I. Alexandrov
}

Chuvash State University named after I. N. Ulyanov, 428015, Moskovskii pr., 15; Cheboksary, Russia

* Corresponding author: cool.karakyrt@ya.ru

This short communication (letter) belongs to the regular issue.

(c) 2021, The Authors. This article is published in open access form under the terms and conditions of the Creative Commons Attribution (CC BY) license (http://creativecommons.org/licenses/by/4.0/).

\begin{abstract}
Polyfunctional silylureas were synthesized by the interaction of 3-aminopropyltriethoxysilane with isocyanates of various structures in an inert aromatic solvent. Commercially available diisocyanates such as isophorone diisocyanate, hexamethylene diisocyanate, 2,4-toluene diisocyanate were used as isocyanates. In this case, freshly distilled toluene was used as a solvent. The structures of the obtained compounds were confirmed by the data of IR and $N M{ }^{1} \mathrm{H}$ spectroscopy. Using the synthesized compounds, formulations of compositions for electrodeposition of a tin-indium alloy on a copper wire were developed. The possibility of using silylureas of various structures as effective surfactants used in the electrodeposition of the tin-indium alloy is shown. The operational characteristics of the obtained wire were investigated, including the wire diameter, coating thickness, tensile strength, electrical resistance, and direct current electrical resistivity.
\end{abstract}

\section{Keywords}

isophorone diisocyanate

hexamethylene diisocyanate

2,4-toluene diisocyanate

3-aminopropyltriethoxysilane

polyfunctional silylureas

electrodeposition

indium-tin alloy

copper wire

electrode

solar panels

Received: 29.06.2021

Revised: 28.08.2021

Accepted: 31.08.2021

Available online: 13.09.2021

\section{Introduction}

One of the most important tasks of increasing the efficiency of photovoltaic solar modules is the search and development of new electrodes that provide high reliability of contact with crystalline silicon, as well as charge transfer in the cell [1]. Copper wire coated with various alloys, which is currently one of the main materials in electrical engineering, is widely used as conductive electrodes [2] The use of such a wire ensures the reliability and protection of solar modules from any external influences and, as a result, the indicator of the durability of the product itself increases [3]. The use of a low-melting alloy on the surface of a copper wire makes it possible to obtain reliable electrical contact with a silver-containing contact grid, which helps to reduce the ohmic resistance between photovoltaic cells [4].

As a rule, wire coating is performed by electroplating or hot dipping [5]. The continuity of the contact of the electrode with monocrystalline silicon directly depends on the quality of the surface of the copper wire and the adhesion strength of the coating to the copper base, which ultimately affects the efficiency of transferring the convert- ed light energy into electricity [6]. To obtain a microscopic adhesive layer of a copper wire coating, electrodeposition of a tin-indium alloy in various electrolytes can be used, but it is impossible to predict the effect of technological additives on the properties of the resulting coating; therefore, in most cases, the electrolyte composition is selected experimentally [6].

For the electrodeposition of the tin-indium alloy acidic and alkaline electrolytes are used. Of acidic electrolytes the following are used: perchlorate, sulfamic, chloride, glycerol, sulfate, boron fluoride electrolytes and others [7].

In the electrical and radio engineering industry, contact-reactive soldering with low-melting eutectic solders based on tin with indium and cadmium is widely used. Existing electrolytes based on $\mathrm{Sn}^{2+}$ salts have low stability, even in the presence of special organic additives [8]. At the same time, there is information in the literature on the successful coprecipitation of tin with indium from acidic and alkaline electrolytes based on $\mathrm{Sn}^{4^{+}}$salts [9], the stability of which is provided by oxyacids. The presence in the electrolyte of a hydroxy acid, for example citric acid, increases the content of the electronegative component of 
the alloy $[10,11]$. To develop a stable, reproducible and controlled technological process for obtaining eutectic composition solders from electrolytes based on $\mathrm{Sn}^{4^{+}}$salts, information is needed on the mechanism and kinetics of the joint discharge of alloy-forming metal ions.

The aim of the work was to increase the adhesion strength of the tin-indium alloy coating on a copper wire by using polyfunctional silylureas that meet the existing requirements for the production of electrodes for solar modules.

It is known that organosilicon compounds are surfaceactive, they can increase the intensity of biological processes of oxidation of organic pollution of wastewater and thereby reduce the anthropogenic load on the environment $[12,13]$.

\section{Experimental}

In this work, we synthesized organosilicon compounds polyfunctional silylureas, which make it possible to increase the affinity of copper wire coated with a tin-indium alloy, improve the spreading of the solder, ensure the necessary activity of the composition, increase the contact angle with the surface during electrodeposition, reduce the surface tension and eliminate the oxidation of the solder surface and a base material to be electrodeposited.

Silylureas I-III received the interaction of 3-aminopropyltriethoxysilane with isocyanates of various structures in the presence of an antioxidant and toluene as a solvent at a temperature of $17-20{ }^{\circ} \mathrm{C}$, while 2,4 -toluene diisocyanate, hexamethylene diisocyanate, isophorone diisocyanate were used as isocyanates of various structures.

Fig. 1 shows a general scheme for the interaction of 3aminopropyltriethoxysilane with diisocyanates. The data on yields, melting points and confirmation of the structures of polyfunctional silylureas are given in Table 1 .

IR spectra were obtained on FT-801 series spectrophotometer in liquid paraffin. ${ }^{1} \mathrm{H}$ NMR spectra were recorded on a Bruker DRX500 spectrometer (500.13 MHz) in DMSO$\mathrm{d}_{6}$, the internal standard was tetramethylsilane. Mass spectra were recorded on a Finnigam MAT INCOS-50 instrument (ionizing electron energy $70 \mathrm{eV}$ ).

In the IR spectra of the obtained products, absorption bands are observed at 3309-3317, 1621-1632, 1562$1570 \mathrm{~cm}^{-1}$, characteristic of $\mathrm{NHC}(\mathrm{O}) \mathrm{NH}$ groups and at 1072-1074 $\mathrm{cm}^{-1} \mathrm{Si}-\mathrm{O}$ bonds. In the ${ }^{1} \mathrm{H}$ NMR spectra, there are characteristic signals belonging to the protons of the following groups $(\delta, \mathrm{ppm}): 0.50-0.56 \mathrm{t}\left(\mathrm{CH}_{2} \mathrm{CH}_{2} \mathrm{CH}_{2} \mathrm{Si}\right)$, 1.39-1.47 $\mathrm{m} \quad\left(\mathrm{CH}_{2} \mathrm{CH}_{2} \mathrm{CH}_{2} \mathrm{Si}\right)$ and at 2.94-3.04 m $\left(\mathrm{NHCH}_{2} \mathrm{CH}_{2} \mathrm{CH}_{2} \mathrm{Si}\right)$. The protons of the urea group correspond to signals at $6.52 \mathrm{t}$ and $8.22 \mathrm{~s}$ for compound (I) and 5.69-5.71 $\mathrm{t}$ and 5.76-5.78 t, for compounds (II) and (III), respectively.

Silylureas are crystalline substances that melt without decomposition.

\section{Results and discussion}

At the next stage, tin-plated copper wires were obtained with the POIN-52 grade Sn-In alloy, which is used as a solder in electrical engineering. It is produced according to TU 48-0220-40-90. The wire thickness is $250 \mu \mathrm{m}$, the coating thickness is from $3-5 \mu \mathrm{m}$, which is applied by hot tinning.

Electrolyte formulations have been developed using synthesized polyfunctional silylureas. The container for electrolyte preparation was filled by three quarters with distilled water, and sulfuric acid was added to it in small portions. Then the solution was cooled to $20-22{ }^{\circ} \mathrm{C}$, and the required amount of tin (II) sulfate was added to it and vigorously stirred to dissolve it. As-obtained solution was filtered. Then indium (III) sulfate was added to the filtrate and stirred until complete dissolution. Next, silylureas (IIII) (as surfactants to increase the affinity of the copper substrate with the alloy), previously dissolved in a small amount of isopropyl alcohol, were added to the solution,

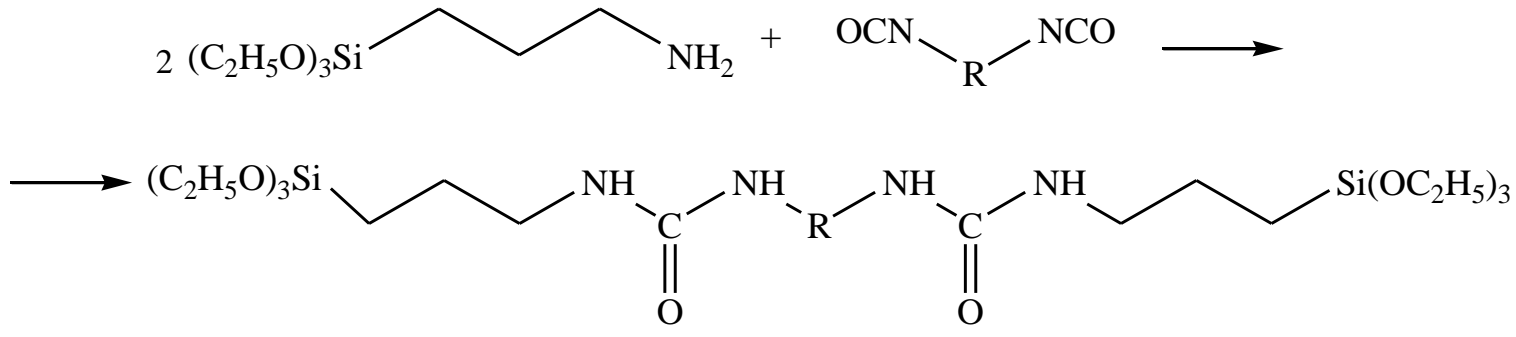

I- III<smiles>[R]=CCCCCCI</smiles>

I II III

Fig. 1 Interaction of 3-aminopropyltriethoxysilane with diisocyanates 
Table 1 IR, NMR ${ }^{1} \mathrm{H}$ spectroscopy data and properties of polyfunctional silylureas

\begin{tabular}{|c|c|c|c|c|}
\hline Name & Reaction yield, $\%$ & $T_{\mathrm{m}},{ }^{\circ} \mathrm{C}$ & IR spectroscopy, $\mathrm{cm}^{-1}$ & NMR spectroscopy, $\delta$, ppm \\
\hline $\begin{array}{l}2,4 \text {-toluylenebis }[\mathrm{N}-3- \\
\text { (triethoxysilyl)propyl]urea } \\
\text { (I) }\end{array}$ & 94.1 & 135 & $\begin{array}{l}\text { v } 3309(\mathrm{NH}), \\
\delta 1632\left(\mathrm{C}=\mathrm{O}_{\text {amide I }}\right), \\
\delta 1562\left(\mathrm{NH}_{\text {amide II }}\right), \\
\text { v } 1072(\mathrm{Si}-\mathrm{O}), \\
\text { v } 1610(\mathrm{ArH}), \\
\delta 765(\mathrm{ArH})\end{array}$ & 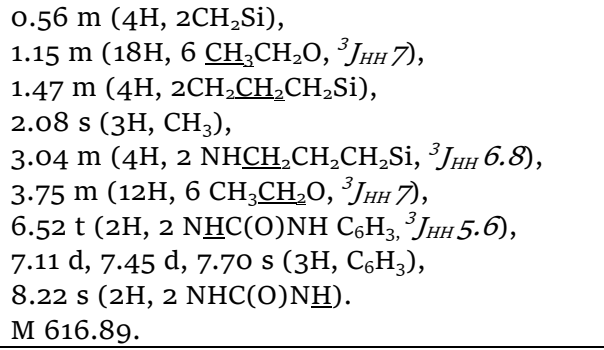 \\
\hline $\begin{array}{l}\text { 1,6-hexamethylenebis[N-3- } \\
\text { (triethoxysilyl)propyl]urea } \\
\text { (II) }\end{array}$ & 95.9 & 122 & $\begin{array}{l}v 3312(\mathrm{NH}), \\
\delta 1691\left(\mathrm{C}=\mathrm{O}_{\text {amide I }}\right), \\
\delta 1570\left(\mathrm{NH}_{\text {amide II }}\right), \\
v 1072(\mathrm{Si}-\mathrm{O})\end{array}$ & $\begin{array}{l}\left.\text { O.50 t ( } 4 \mathrm{H}, 2 \mathrm{CH}_{2} \mathrm{Si}_{1}{ }^{3} J_{H H} 8.45\right), \\
1.14 \mathrm{t}\left(18 \mathrm{H}, 6 \mathrm{CH}_{3} \mathrm{CH}_{2} \mathrm{O},{ }^{3} J_{H H} 7\right), \\
1.22 \mathrm{~m}\left(4 \mathrm{H}, 2 \mathrm{CH}_{2}\right), \\
1.33 \mathrm{~m}\left(4 \mathrm{H}, 2 \mathrm{CH}_{2}\right), \\
1.39 \mathrm{~m}\left(4 \mathrm{H}, 2 \mathrm{CH}_{2} \mathrm{CH}_{2} \mathrm{CH}_{2} \mathrm{Si}\right), \\
2.94 \mathrm{~m}\left(2 \mathrm{NHCH}_{2} \mathrm{CH}_{2} \mathrm{CH}_{2} \mathrm{Si}, 2 \mathrm{NHCH}_{2},{ }^{3} J_{H H} 6.8\right), \\
3.73 \mathrm{k}\left(12 \mathrm{H}, 6 \mathrm{CH}_{3} \mathrm{CH}_{2} \mathrm{O},{ }^{3} J_{H H} 7\right), \\
5.71 \mathrm{t}, 5.76 \mathrm{t}\left(4 \mathrm{H}, 2 \mathrm{~N} \underline{\mathrm{HC}}(\mathrm{O}) \mathrm{NHCH}_{2},{ }^{3} J_{H H} 5.6\right) . \\
\text { M } 610.93 .\end{array}$ \\
\hline $\begin{array}{l}\text { isophoronbis[N-3- } \\
\text { (triethoxysilyl)propyl]urea } \\
\text { (III) }\end{array}$ & 94.3 & 171 & $\begin{array}{l}v 3317(\mathrm{NH}), \\
\delta 1624\left(\mathrm{C}=\mathrm{O}_{\text {amide I }}\right), \\
\delta 1563\left(\mathrm{NH}_{\text {amide II }}\right), \\
v 1070(\mathrm{Si}-\mathrm{O})\end{array}$ & 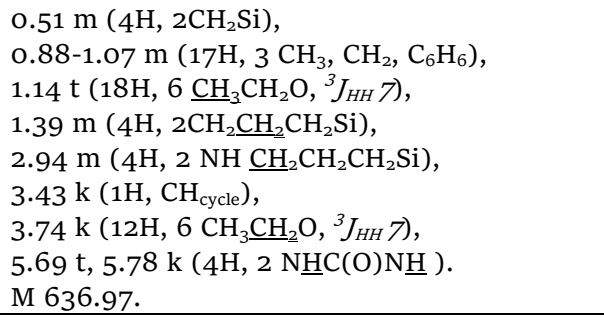 \\
\hline
\end{tabular}

1,2-propylene glycol and the remaining amount of isopropyl alcohol were added to a predetermined level.

Co-deposition of Sn-In occurs electrochemically using the following deposition mode:

- Temperature, ${ }^{\circ} \mathrm{C}$ - 18-35;

- Cathode current density, A/dm² - 0.5-7.0;

- Current output, \% - 80-98;

- The content of indium in the alloy, wt\% - 40.0-52.0.

Measurement of the wire diameter, its deviation and ovality, the degree of alignment was carried out according to GOST 12177 using a video measuring system NVM2010D. The determination of the thickness and composition of the coating was carried out in accordance with GOST 9.302 using an X-STRATA 920 X-ray fluorescence analyzer of coatings. The determination of the density was carried out by hydrostatic weighing. Determination of tensile strength, yield strength, and relative elongation at breaking of the wire were carried out in accordance with GOST 10446 using an optical non-contact video extensometer M-VIEW and on a tensile testing machine RKM-1.1. The determination of the specific and electrical resistance was carried out according to GOST 7229. The adhesion strength of the adhesion of the coating of the tin-indium alloy with the copper base was studied by examining the coated wire after twisting with using the video measuring system NVM-2010D.

Tables 2 and 3 show the comparative characteristics of the developed electrolyte compositions, the properties of the electrolyte compositions of copper wire coated with a tin-indium alloy and the modes of its electrodeposition.

Table 2 Electrolyte compositions for the production of copper wire coated with tin-indium alloy

\begin{tabular}{|c|c|c|c|c|}
\hline \multirow{2}{*}{ Components, g / 1} & \multicolumn{4}{|c|}{ Compositions } \\
\hline & Prototype & 1 & 2 & 3 \\
\hline Tin sulphate (in terms of metal) (II) & $2-15$ & 17 & 17 & 17 \\
\hline Indium sulfate (in terms of metal) (III) & $5-30$ & 20 & 20 & 20 \\
\hline Sulfuric acid & $90-100$ & 80 & 85 & 80 \\
\hline Laureth 9 & $1-2$ & - & - & - \\
\hline 2,4-toluylenebis [N-3-(triethoxysilyl)propyl] urea (I) & - & 1 & - & - \\
\hline 1,6-hexamethylenebis [N-3-(triethoxysilyl)propyl] urea (II) & - & - & 1 & - \\
\hline Isophoronbis [N-3-(triethoxysilyl)propyl] urea (III) & - & - & - & 1 \\
\hline Isopropyl alcohol & - & 10 & 10 & 10 \\
\hline Formalin ( $37 \%$ solution) & 5-7 & - & - & - \\
\hline 1,4-Butanediol ( $35 \%$ solution) & $10-15$ & - & - & - \\
\hline Propane-1,2-diol & - & 20 & 25 & 15 \\
\hline
\end{tabular}


Table 3 Properties of coatings obtained by electrodeposition of a tin-indium alloy

\begin{tabular}{|c|c|c|c|c|}
\hline \multirow{2}{*}{ Properties } & \multicolumn{4}{|c|}{ Compositions } \\
\hline & Prototype & 1 & 2 & 3 \\
\hline Cathode current density, $\mathrm{A} / \mathrm{dm}^{2}$ & $0.5-7.0$ & 20.0 & 20.0 & 20.0 \\
\hline Temperature, ${ }^{\circ} \mathrm{C}$ & $15-30$ & 18 & 18 & 18 \\
\hline Alloy current output, \% & $37-97$ & 87 & 85 & 80 \\
\hline Indium content in the alloy, $\%$ & $0.5-56.0$ & 41.0 & 42.0 & 40.0 \\
\hline Appearance of coatings & shiny & \multicolumn{3}{|c|}{$\begin{array}{l}\text { smooth shiny surface and continuous coating along } \\
\text { the entire length of the wire }\end{array}$} \\
\hline Leveling degree & $0.20-0.60$ & 0.85 & 0.80 & 0.80 \\
\hline Adhesive strength test & & + & + & + \\
\hline Wire diameter, $\mu \mathrm{m}$ & - & 250 & 250 & 250 \\
\hline Coating thickness, microns & 6 & 0.1 & 0.1 & 0.1 \\
\hline Coating density, $\mathrm{g} / \mathrm{cm}^{3}$ & - & 8.9 & 8.9 & 8.9 \\
\hline Tensile strength of wire, $\mathrm{N} / \mathrm{mm}^{2}$ & - & 242 & 238 & 240 \\
\hline Relative extension, $\%$ & - & 23 & 24 & 21 \\
\hline DC electrical resistance at $20^{\circ} \mathrm{C}, \mathrm{Ohm} / \mathrm{m}$ & - & 0.35 & 0.35 & 0.35 \\
\hline $\begin{array}{l}\text { Specific electrical resistance for direct current } \\
\text { at a temperature of } 2 \mathrm{O}^{\circ} \mathrm{C}, \mathrm{Ohm} \mathrm{mm}^{2} / \mathrm{m}\end{array}$ & - & 0.0172 & 0.0174 & 0.0176 \\
\hline
\end{tabular}

As can be seen from Tables 2 and 3, the copper wires obtained by this method with a coating based on a tinindium alloy from the proposed electrolyte have a smooth shiny surface and a continuous coating with a thickness of $0.1-1.0 \mu \mathrm{m}$ along the entire length of the wire, strong adhesion to a copper base and the presented modes of electrodeposition can be used to obtain a microscopic adhesive layer of a copper wire coating based on a tinindium alloy.

\section{Conclusions}

Polyfunctional silylureas were synthesized via the interaction of 3-aminopropyltriethoxysilane with isocyanates of various structures, which were used as active surfactants in the electrodeposition of a tin-indium alloy. The qualitative and quantitative composition of the electrolyte for the electrodeposition of the tin-indium alloy on copper wire and the production of electrodes for solar modules was selected based on the use of effective modifiers that increase the adhesive strength of the coating on a copper substrate. It was found that the synthesized polyfunctional silylureas increase the affinity of copper wire coated with a tin-indium alloy and, consequently, the binding power and adhesive strength. The use of the developed electrolyte with the polyfunctional silylureas in the electrodeposition of a tin-indium alloy on a copper wire makes it possible to obtain an electrode for solar panels with high physical, mechanical and operational properties.

\section{Acknowledgments}

The research was carried out in Chuvash state University within the implementation of a comprehensive project under the contract No. 2019/0837/1202-19 dated September 19, 2019 with the financial support of the Ministry of Education and Science of Russia under the Agreement No. 075-11-2019-047 dated November 25, 2019 and Russian Foundation for Basic Research (RFBR), project number 20-33-90269.

\section{References}

1. Prospects for Energy Technologies 2008. Scenarios and Strategies until 2050 [Internet]. International Energy Agency. OECD / IEA, 2008. p. 10-15 [cited 29.07.2021]. Available from: https://iea.blob.core.windows.net/assets/oe19oefbdaec-4116-9ff7-eao97f649a77/etp20o8.pdf

2. Lobanov ML, Kardonina NI, Rossina NG, Yurovskikh AS. Zashchitnye pokrytiya : uchebnoe posobie [Protective coatings: textbook]. Yekaterinburg: Ural Federal University Publishing House; 2014. p. 87-89. Russian.

3. Vinokurov EG, Margolin LN, Farafonov VV. Elektroosazhdenie kompozitsionnykh pokrytiy [Electrodeposition of composite coatings]. Izvestiya vysshikh uchebnykh zavedeniy. Seriya: Khimiya i khimicheskaya tekhnologiya., 2020;63(8):4-38. Russian.

4. Bessel VV, Kucherov VG, Mingaleeva RD. Izuchenie solnechnykh fotoelektricheskikh elementov [Study of solar photovoltaic cells]. Moscow: Publishing Center of the Russian State University of Oil and Gas (NRU), 2016. p. 36-37. Russian.

5. Toshio I, Yuichi M, Toshihide U, Hajime K, Susumu Y, Masayuki T. Electrochemical deposition of a Ni - fluoroplastic composite film on the powder of a hydrogen-absorbing $\mathrm{AB}_{5}$ type alloy. Nippon kagaku kaishi. 2001;7:387-391. 
6. Zorkina OV, Perelygin YuP. Elektroosazhdeniye splava olovoindiy iz sulfatnogo elektrolita [Electrodeposition of a tin - indium alloy from a sulfate electrolyte]. Materialy Vserossiyskoy konferentsii «Progressivnaya tekhnologiya i voprosy ekologii v galvanotekhnike i proizvodstve pechatnykh plat» [Book of abstracts of "Progressive technology and environmental issues in electroplating and printed circuit board production" conference]. Penza: DNTP, 200o. p. 48-49. Russian.

7. Fursova NYu. Elektroosazhdeniye splava Sn-Sb iz sulfata elektrolity s organicheskimi dobavkami [Electrodeposition of $\mathrm{Sn}-\mathrm{Sb}$ alloy from sulfate electrolytes with organic additives] [dissertation]. Moscow: Mendeleev University of Chemical Technology, 2000. 146 p. Russian.

8. Kryvtsov AK, Khamaev VA, Gryaznova GI, Pavelyeva LA, Karabinov YuV, inventors. Elektrolit dlya osazhdeniya pokrytiy iz splava olovo-indiy. USSR patent SU 865997 A1. 23 Sep 1981. Russian.

9. Perelygin YuP. Elektroosazhdeniye indiya i splavov na ego sonove. Raspredeleniye toka mezhdu sovmestnymi reaktsiami vosstanovleniya ionov na katode [Plating indium and its alloys. Current distribution between joint recovery reactions of ions reduction at the cathode] [dissertation]. Moscow: Mendeleev University of Chemical Technology. 1996. 235 p. Russian.
10. Kotov VL, Gryaznova Gl, Chuvilyaeva TV, Kryvtsov AK. Izvestiya Vysshikh Uchebnykh Zavedeniy Seriya "Khimiya I Khimicheskaya Tekhnologiya”. 1985;28(9):70-73. Russian.

11. Belevskiy SS. Indutsirovannoe soosazhdenie nanokristallicheskikh Co-W pokrytiy I ikh mekhanicheskie svoystva [Induced coprecipitating of nano-crystalline Co-W coatings and their mechanical properties] [dissertation]. Chisinau: Institute of Applied Physics; 2012. 142 p. Russian.

12. Patianova AO, Ivanova KYu, Rogozhina LG, Kuzmin MV, Semenov VL. Improving the environmental production of electrodes for solar panels. Chimica Techno Acta. 2020;7(4):186191. doi:10.15826/chimtech.2020.7.4.09

13. Ivanova KYu, Kuzmin MV, Kol'tsov NI. Synthesis and research of polyfunctional siliconcontaining amines - new promoters of adhesion. Chimica Techno Acta. 2020;7(4):199-203. doi:10.15826/chimtech.2020.7.4.11 